\title{
Chapter 5 \\ Conflict Analyses: A Methodology for Exploring Children's Cultural Formation in Early Childhood Education
}

\author{
Liv Torunn Grindheim
}

\subsection{Introduction}

In our contemporary society, education is often presented in a uniform and universal way to solve contemporary problems (Biesta, 2015). Through early interventions, early childhood educational (ECE) institutions are supposed to neutralise class differences (NOU, 2009), provide school readiness for bilingual children (Drange \& Telle, 2011; NOU, 2011; Stortingsmelding, 2003-2004) and prevent behavioural problems and school dropouts (Webster-Stratton, 1999). Behavioural problems are often connected to children's inability to solve conflicts and to children's resistance towards planned activities and ways to behave. There seems to be a common aim to curb conflicts and resistance (Grindheim, 2013, 2017).

To obtain these aims, reforms, which can be interpreted as a political panic reaction to a more open and rapidly shifting society and globalisation, are to be implemented (Trippestad, 2017). These reforms, attempting to engineer a social utopia through education, are often implemented by equipping the individual child with previously defined competences; the earlier, the better. These reforms often refer to single-dimensional, causal research. Hedegaard (2009) and her fellow psychologists criticise research approaches that study child development from such a functional, one-dimensional perspective. She argues that 'demands for a scientific approach have led to several one-dimensional conceptions of development, where the focus has been on the development of different psychological functions and competencies' (p. 64). In line with sociologists and anthropologists (Corsaro, 1997; James, Jenks, \& Prout, 1998; Rogoff, 2003), she emphasises the need to study children's social activities localised in time and space. To obtain an understanding of what to challenge and improve in the everyday practices of ECE, consideration

L. T. Grindheim $(\bowtie)$

Western Norway University of Applied Sciences, Bergen, Norway

e-mail: Liv.Torunn.Grindheim@hvl.no 
must be given to the perspectives of both the involved actors - the teachers and the children - the specific activity that is to be performed and the conditions for acting. In this article, I see nature as a part of the context and as a part of the culture. I therefore relate to the conflict in the often-presented dichotomous concepts of nature and culture, as well as conflicts between values and motives versus conditions and demands, from four contextual perspectives: conflicts in the activity, institutional conflicts, cultural conflicts and conflicts in how nature is positioned in the activity, in the institution and in Norwegian culture.

Building on Dahlberg, Moss, and Pence (2007), quality is understood as accommodating diversity, subjectivity and multiple perspectives in temporal and spatial contexts (p. 103). Accommodating for plurality and variety can form a milieu for children from different classes, genders and ethnicities to develop, learn and achieve their cultural formation. To depict the multifactorial relations that work together to obtain better quality in ECE, there is, on the one hand, a need for rich material for analysis that emphasises both the context and the way in which individuals act. On the other hand, there is a challenge to analyse this material in a systematic and transparent manner that also includes the investigative and imaginative elements of activities such as explorative play. To find a way to meet these challenges, this chapter is structured around the question: How can we analyse explorative play? The aim is to illustrate a multifactorial, analytical method for analysis that is coherent and transparent, emphasising both the active participants and their context by starting with an everyday activity. Through the presentation of this method, we can see how a situated activity is closely connected to the larger context. The activity, institutional factors, cultural conditions and the construction of nature are woven into the present activity and are therefore dimensions that should be taken into consideration to improve pedagogical practices in ECE. It also indicates that research and methods for analysis should be constantly evolving. The basic ideas in dialectic approaches make space for challenging theories and methodology from experiences attained when doing research.

\subsection{Constructing Theoretical Dialectical Knowledge}

Any method for analysis is closely connected to an understanding of knowledge and how knowledge is constructed. Hedegaard (2008) outlines how conceptual knowledge is the core of scientific knowledge and points to two different epistemological approaches for knowledge construction: empirical knowledge and theoretical dialectical knowledge. I place my discussion of how to analyse explorative play under the construction of theoretical dialectical knowledge, understood as an approach whereby research material from everyday activities is inferred by theoretical concepts. At the same time, looking closely into the activities also calls for additional or new concepts to challenge what has been taken for granted in theoretical concepts. Several researchers point to the importance of more transparency when analysing experiences from observing or participating in the everyday activities in ECE 
institutions (Nordenbo \& Moser, 2009; Ødegaard, 2015). There have been some valuable studies, and I will point to those that have inspired my contribution to ways of analysing. All of them concern the activities, the cultural contexts in which the activities take place and the researcher's knowledge construction.

\subsubsection{Constructing Knowledge by Emphasising Conflicts}

Rogoff's (2003) analyses emphasise culturally embedded transitions. She outlines how 'cultural practices often bring individual development explicitly into relation with social and cultural expectations' (p. 152). These transitions, such as an infant's first laugh in the Navajo culture, starting school, losing a first tooth, getting married, parenthood and so on, form central shifts for a human as well as influence development. By pointing to transitions, she reveals how the expectations for what a child can manage are closely connected to the culture in which the children live their lives and thereby challenge the causality between age and normal development that is presented in individual psychological theories about children's development according to age. Rogoff (2003) argues that 'Instead of assuming that age transitions are inherent to children's biological maturation, independent of circumstances, it is reasonable to ask how children in a particular community become responsible enough to take care of themselves in the ways expected and supported in that community. The impressive changes that come with biological maturation are accompanied by powerful changes in communitywide expectations and opportunities for children's participation in the activities in the community' (p. 171). Thus, social and cultural perspectives are brought forward as important conditions for children's development, although her analysis does not offer tools to conceptualise the involved children's intentions in the analysed activities.

In line with Rogoff, Hedegaard (2009) illustrates how transitions from institutions such as home to early childhood education, or from early childhood education to school, represent a shift in what is expected from the children, and that the shift from - or among - different institutions condition children's experiences and development. Hedegaard (2014) outlines a model for analysis that illustrates four contextual perspectives that also are interrelated: the people, the activity setting, the institutional perspective and the cultural perspective (p. 192). At the same time, her model, in contrast to Rogoff's, describes children as intentional actors who influence their own, their peers' and their institutions' everyday life and development. According to Hedegaard (2008), 'The easiest way to understand a child's intentions is to note when there is a conflict where the child cannot do what he or she wants to do and cannot realise the projects in which the child is engaged, and the intention the child shows through his or her actions' (p. 19). In contrast to the goal of curbing conflicts, the tensions or conflicts between children's intentions and what is expected in the institutions they are attending are perceived as something that provides room for development. Contextual conditions can be depicted by tracing the conflicts that occur between children's values and motives versus the conditions and demands 
from personal, institutional and societal/cultural perspectives. In this chapter, the way the involved children deal with these conflicts through play are understood as ways of exploring something that is important to them. Although there are many reasons for children's exploration in play, conflict is the central concept for exploration in my illustration of how to analyse explorative play.

Tensions or conflicts—labelled as dilemmas between ideologies as formulated in framework plans and ideologies underlying popular culture when it comes to violence and gender-are also forthcoming in Ødegaard's (2015) careful and transparent illustration of an analysis process. The dilemmas referred to are embedded both in the didactical practice in which the activities are performed and in what is of interest for the researcher. She illustrates how epistemological reflexivity on the making of knowledge from empirical data can be transparent through creating more distance to the activities by using analytic schemes that are expanded by theoretical concepts and perspectives. Thus, what at first glance was obvious is challenged by new concepts. In addition, a closer awareness of what was actually said and done, and how the involved child used artefacts (the telescope), gives new insight. Each step is explained and illustrates the importance of researchers rereading and reflecting to challenge what, at first, seems to be important.

I perceive the way Ødegaard (2015) constructs knowledge in her dialogue with research material and theory as theoretical dialectical knowledge construction. Hedegaard (2008) illustrates how researchers in this approach construct knowledge by explicit categories or the theoretical consideration, distance themselves from the specific situation, trace the specific research situation so that more general relations can be formulated, and build and use conceptual frames in order to create and understand the material in relation to the research aim. In line with Ødegaard, Hedegaard (2008) points to the analysis as an intentional orientation of the researcher. Therefore, the ways in which the participants interact, the conflicts between the various participants' intentions and the projects in the activity, and the competences and motives that can be seen in the participants' interaction in their social situations are to be conceptualized. In my outline of how to analyse explorative play, a videotaped situated activity is at the core, and interactions are emphasised by tracing conflicts between values and motives versus conditions and demands from several contextual perspectives. I also aim to make my analysis transparent, explaining my method and my aims-knowing that the researcher is an intentionoriented person and the constructor of knowledge.

\subsubsection{Analysis from a Thematic Perspective}

Hedegaard (2008) also refers to interpretation on a thematic level that makes it possible to formulate new conceptual relations within a problem area. The involved children in the material that forms the examples for how to analyse children's explorative play are engaged in imaginative role-playing. Role-play is also referred to as pretend play, fantasy play, imaginative play, free-flow play, dramatic play or 
socio-dramatic play (Bruce, 1991; Fleer, 2010; Sadownik, 2017). In these kinds of play, the manifested imaginary situation gives a latent and implicit predomination of what roles the children might take; the children act out their performance attuned to the imaginary situation (Winther-Lindqvist, 2009).

The illustrating analysis theme (children playing dragons) is based on Vygotsky's (2016) texts about play, referred to as imaginative role-play (Grindheim, 2018). According to Vygotsky $(2004,2016)$, knowledge, imagination and creativity in collaborative play are the leading line of development in the preschool years, the sources of development and the zone of proximal development that determines the domain of transitions to which the child has access. Play, according to Vygotsky, has three components: In play, children create an imaginary situation; they take on and act out roles; and they follow a set of rules determined by specific roles (Bodrova, 2008; Vygotsky, 2016). Vygotsky (2016) states that all imaginative situations contain rules in a concealed form. He writes that there is 'no such thing as play without rules and the child's particular attitude towards them'. Thus, understanding play as free and spontaneous is challenged. In role-play, children are balancing the paradox that play, on the one hand, allows them to achieve unrealisable desires in an imaginary situation. On the other hand, children in play regulate their behaviour within the rules of the play. The contradictions and relations between the imaginative and reality are met in children's imaginative play (Vygotsky, 2004). Even though play cannot be performed without experiences from reality, the imagination also affects reality and children's intellectual development. Reality and imagination are interwoven. Therefore, conflicts between the theme of the play and children's intentions can also be revealed.

\subsubsection{Analysis from the Perspective of Cultural Formation in Nature}

In line with Vygotsky (2016) and Hedegaard (2009), children are seen as active in their learning and development. Children's learning and cultural formation are contextualised, situated, mediated and embedded in their given cultural context. Building on Ødegaard and Krüger (2012), cultural formation is understood as an always present and continuous process. Ødegaard and Krüger promote cultural formation as a descriptive concept that describes an act of humans in relation to the conditions in their given culture. Both the process (act) and the result of being a part of the activity are embedded in cultural formation. The children, the process, the activity and the context are all parts of the involved children's exploration and are traced through emerging tensions and conflicts. Understanding both the process and the result as cultural formation provides an opportunity for analysing how children are formed by their culture at the same time as they are influencing their own formation, the people they are involved with and their contexts.

Research done in kindergartens in the Norwegian culture raises the notion of nature. Witoszek (1991) states that nature is given a temporal and cultural dimen- 
sion, in a transgression of the distinct nature/culture dimension in Norway. She claims that nature serves as a base for Norwegians' national identity. This identity is traced in the emphasis on outdoor activities, the happiness attained while staying at a remote family cabin, strong egalitarian impulses, the position of Norwegian farmers and Næss' (2005) in-depth ecological utopia, where humans, animals, plants, woods, and sea are connected in a holy peace. It is a place where there is no need for alcohol or stimulating drugs, because there is no boredom. From this, I conclude that nature is embedded in the cultural tradition in Norway and in Norwegian ECE—although culture and nature most often are seen as dichotomies.

Payne (2018) challenges the cultural-historical approach by addressing the necessity to take into consideration theorisation of children's experiences of the temporal-spatial dimensions of nature as part of everyday life (home, gardens, woods, open spaces, urban settings, neighbourhood). In contrast to Payne, I do not meet this need by a posthumanistic approach but by adding another perspective in the analysis. Instead of trying to overcome dichotomies (here, between nature and culture), which is a common aim in a posthumanistic approach (Braidotti, 2016), I emphasise the conflicts embedded in the dichotomous concepts to construct insight. I see this as coherent with the tension between children's values and motives while meeting conditions and demands in their contexts. Thus, both the different perspectives and the ongoing activity are analysed from an understanding of conflict as a core concept for further insight and knowledge construction.

\subsubsection{Illustrating a Multifactorial Methodology for Analysis to Construct Theoretical Dialectical Knowledge}

Fleer and Veresov (2018) point to many interesting and valued studies in ECE. The researchers they refer to also describe their contributions to knowledge in the field through more or less transparent analysis. Despite the outspoken need for more transparency when it comes to qualitative analysis, however, there is a limited number of articles with the main aim of illustrating how to do analysis when activities are understood as situated in institutions, society/culture and nature. To contribute to this area, I outline how to trace conflicts between values and motives versus conditions and demands from four contextual perspectives, which are inspired by Hedegaard $(2009,2014)$. The first perspective is in an activity that I label as explorative play, the second is from the institutional perspective, the third is from the cultural perspective and the fourth is from the perspective of how nature is positioned in the activity. This elaboration of the model is in line with my understanding of knowledge construction as theoretical dialectical knowledge. What happens in the activity challenged my theoretical framework, and the dialectical tension or conflict between material and theory constructed further insight about how to analyse explorative play. 


\subsection{Method and Material}

Since the analysis is central to this article, I present only a brief overview of the method and material that form the foundation of my analysis.

The material that forms the basis for my analysis is from a study done in collaboration with a kindergarten institution in Norway from April 2016 to August 2017. Five teachers at this kindergarten made videotapes to illustrate children's activities that they found to be of special interest and value. I visited their institution to select the videos and interview the teachers who recorded the activities, meeting one teacher at a time as well as the children in the particular video(s). I visited the institution 11 times for $2-4 \mathrm{~h}$ to do the interviews. Altogether, I obtained 13 videotapes of activities that differ in length from 1.11 to $10 \mathrm{~min}$-all followed by comments from the teachers who made the recordings; and seven videos also include comments from the involved children. The videos contain activities that took place over the period of 1 year and involve different teachers, children, activities and places, but all from the same institution.

The materials to illustrate how explorative play can be analysed are: a video (9 min and $17 \mathrm{~s}$ ) of four boys playing dragons, the transcribed conversations with the teacher who recorded the video, the transcribed conversation with the involved children and their teacher, the local curriculum for this year in their kindergarten, the aims and tasks for Kindergartens in Norway (UDIR, 2017) and our Western (Christian) traditional interpretation of dragons (Kværne, 2012) and the Norwegian/ Nordic closeness/understanding of nature (Witoszek, 1991). The recorded activity forms the basis for the analysis throughout all four perspectives in my analysis.

\subsection{Analysis}

Although how to do the analysis is at the core of this article, so is the question of the purpose of the analysis - the research question is an always relevant object in any research. My suggestions for a way to analyse draws on the purpose of the analysis, which is to discover what children are exploring in their play. What children are exploring can depict an important insight into their experiences, interests and everyday life. This insight can also reveal conditions, such as structures, routines and content, that can be challenged to improve pedagogical practices in ECE institutions. Since the activity forms the material basis for the analysis, I start the illustration of my analysis by presenting a short summary of the activity:

Four boys were playing dragons, 'flying' while running with their arms spread, using most of the room. They were sleeping in the area for family play, followed by sitting down on a bench and making up stories involving dragons that soon led to acting out the story instead of telling it. As dragons, they ran from the area for family play and were suddenly caught in a cage. Luckily, they were soon able to escape when one of them realised that they were 
able to blow fire and thereby melt the lock on the cage. The dragons were also fighting, rolling over each other on the floor. Occasionally, they were transformed into crocodiles and firefighters, and they drove a car while attacked by other dragons. Thereafter, they were all involved in a war. After some time, one of the boys withdrew from the physical play and offered water to the dragons. A second boy also started to play a lesser part in the physical involvement, although the two who played lesser parts apparently still related to the theme of the play. After some minutes, the boy who served water to the dragons uttered that he wanted to play with Lego. He suggested it several times to the other boy, who also withdrew from the physical game. By the end of the video, the four of them had split into two groups of two, in which one group played with Lego and the other group continued their game of dragons (Grindheim, 2018, p.7).

The question that guided my analysis was: What are the children in the video exploring while playing dragons? Exploring was traced through conflicts caused by differences in values and motives while meeting conditions and demands in the context, from the perspective of the activity, the kindergarten, the Norwegian culture and the way nature is positioned in the activity. To make my analysis more transparent, I will illustrate my analysis in four steps, illustrated in five tables. The fifth table is a synthesis of the first four, and it describes how I interpret what was being explored from the conflicts in the activity, from an institutional perspective, from a cultural perspective and from a perspective that includes the position of nature. The activity of children playing dragons is at the core according to any level of analysis - it is the base for the analysis.

\subsubsection{Conflicts in the Activity (Imaginative Play)}

Material for analysis comprises the recorded activity and the notes on the children's and their teacher's comments about the video. According to the teacher, all four of the children were playing together for several minutes. That was also the reason their teacher made this video, and the collaborative play had gone on for a while before she started to record the video. She had never seen the four of them playing together in a peer group before. Despite all four playing together, there were several suggestions from one of the boys to start building with Lego. By the end of the video, the four of them had split into two groups of two, in which one group played with Lego and the other group continued their game of dragons. From the video and the comments, a conflict appears between playing together as four versus as two, in two-person groups.

In addition, the comment from the boys who were fighting, as dragons do, that they did not fight ('I tickled you') appears as a conflict between the theme of the play-being evil dragons that are fighting and killing-versus how friends act. Thereby, a conflict can be traced between the frames in the imaginative play and the children involved (Table 5.1). 
Table 5.1 Conflicts in the activity

\begin{tabular}{|c|c|c|c|c|}
\hline & Social situation & Values and motives & $\begin{array}{l}\text { Conditions and } \\
\text { demands }\end{array}$ & Conflicts \\
\hline Activity & $\begin{array}{l}\text { Four boys playing dragons, } \\
\text { making stories, fighting, } \\
\text { catcher in a cage, escape, } \\
\text { driving cars while being } \\
\text { chased in a war between } \\
\text { dragons. They are also } \\
\text { changing roles to become } \\
\text { dragons, firefighters and } \\
\text { crocodiles. }\end{array}$ & $\begin{array}{l}\text { The children told us } \\
\text { that 'this is the first } \\
\text { time we are playing } \\
\text { this kind of play } \\
\text { inside'. } \\
\text { 'We became } \\
\text { friends'. } \\
\text { When watching the } \\
\text { fighting, the } \\
\text { comment from the } \\
\text { attacking boy was, } \\
\text { 'We did not fight, I } \\
\text { tickled you'. }\end{array}$ & $\begin{array}{l}\text { Some } \\
\text { knowledge } \\
\text { about these big, } \\
\text { ugly, dangerous } \\
\text { animals } \\
\text { Being a part of } \\
\text { the game/play }\end{array}$ & $\begin{array}{l}\text { Playing together } \\
\text { for a long time } \\
\text { span for the first } \\
\text { time versus } \\
\text { splitting into two } \\
\text { two-person } \\
\text { groups. } \\
\text { We became } \\
\text { friends (in the } \\
\text { game) being } \\
\text { friends/friendly } \\
\text { (facing danger } \\
\text { together as } \\
\text { firemen, chased } \\
\text { in a war) I tickled } \\
\text { you (which is } \\
\text { friendly) versus } \\
\text { being dragons } \\
\text { (fighting and } \\
\text { killing) }\end{array}$ \\
\hline
\end{tabular}

\subsubsection{Conflicts from an Institutional Perspective}

Material for the analysis comprises the recorded activity, the notes on the teacher's comments about the video, the transcribed interview with the teacher and this kindergarten's plan for the year. In addition, some of the children's comments were seen as relevant to the institutional perspective. According to the teacher, the furniture in the room was not usually used for this kind of play. A conflict appears between the artefacts and the furniture and the usual use of the room versus the theme of play that requires space for running and collaborative movements involving the whole body. I interpret that as a conflict between the teacher's values and motives versus the conditions and demands in the institution, and a conflict between didactical practices aimed at prescribed definitions of good play versus making friends and making room for play where children are in control of the temporary content of their kindergarten (Table 5.2).

\subsubsection{Conflicts from a Cultural Perspective}

Material for analysis comprises the recorded activity, the notes on the teacher's comments, the Frameworkplan for content and tasks in Norwegian kindergartens (UDIR, 2017) and our Western (Christian) traditional interpretation of dragons (Kværne, 2012). According to the teacher, it was hard for these children to partici- 
Table 5.2 Conflicts from an institutional perspective

\begin{tabular}{|c|c|c|c|c|}
\hline & Social situation & Values and motives & $\begin{array}{l}\text { Conditions and } \\
\text { demands }\end{array}$ & Conflicts \\
\hline Activity & $\begin{array}{l}\text { The } \\
\text { imaginative } \\
\text { play of the } \\
\text { four boys } \\
\text { playing } \\
\text { dragons }\end{array}$ & & & \\
\hline Institution & $\begin{array}{l}\text { In free-play } \\
\text { time, children } \\
\text { are divided in } \\
\text { groups in the } \\
\text { kindergarten }\end{array}$ & $\begin{array}{l}\text { The teacher } \\
\text { comments about why } \\
\text { she made room for } \\
\text { (this) play: 'Play is a } \\
\text { space for freedom } \\
\text { and joy. These boys } \\
\text { do have their needs. } \\
\text { Here they are in } \\
\text { control, having fun } \\
\text { escaping from their } \\
\text { everyday life'. } \\
\text { 'The good life for } \\
\text { children is in play'. }\end{array}$ & $\begin{array}{l}\text { According to the } \\
\text { teacher, this kind } \\
\text { of play was } \\
\text { conditioned by } \\
\text { 'Making social } \\
\text { play situations } \\
\text { transparent and } \\
\text { thereby accessible } \\
\text { for children'. } \\
\text { In the plan for } \\
\text { this particular } \\
\text { kindergarten, play } \\
\text { is emphasised and } \\
\text { described as } \\
\text { activities that } \\
\text { 'give the children } \\
\text { opportunities to } \\
\text { face scary themes } \\
\text { and the unknown. } \\
\text { In play, they can } \\
\text { cultivate each } \\
\text { other and } \\
\text { cultivate emotions } \\
\text { and experiences' } \\
\text { (the plan for the } \\
\text { year 2016, p. 4). } \\
\text { 'Materials to } \\
\text { inspire (this kind } \\
\text { of) play'. }\end{array}$ & $\begin{array}{l}\text { According to the } \\
\text { teacher: } \\
\text { 'There are limited room } \\
\text { for these kinds of play } \\
\text { (tumbling, fighting, } \\
\text { walking, as you need } \\
\text { when playing Captain } \\
\text { Sabeltann) in } \\
\text { kindergartens. The } \\
\text { room they are playing } \\
\text { in is usually not for } \\
\text { role-play, but for } \\
\text { activities on tables' } \\
\text { (games, drawings, } \\
\text { painting, etc..), versus } \\
\text { the teacher's valuing of } \\
\text { the children's initiative, } \\
\text { the activities they are } \\
\text { generating in the given } \\
\text { and planed didactical } \\
\text { practice and even the } \\
\text { plan for this } \\
\text { kindergarten. }\end{array}$ \\
\hline
\end{tabular}

pate in peer groups, and in more regulated and prescribed required activities. They needed to meet in a common theme that also required openness for variety of ways to act, close to experiences that were of importance for them. From this, a conflict emerges between kinds of play that are often emphasised in education versus influence from cultural fiction's creatures. In addition, a conflict appears between worries for changes in our democracy, children leaving school, emphasis of early interventions to prevent behavioural problems and crime versus play as the leading line for children's development (Vygotsky, 2016). I interpret this as a conflict between being dragons and crocodiles that are not good friends, not socially competent nor good citizens (Kværne, 2012) they fight, they are lonely and they abduct 
Table 5.3 Conflicts from a cultural perspective

\begin{tabular}{|c|c|c|c|c|}
\hline & $\begin{array}{l}\text { Social } \\
\text { situation }\end{array}$ & $\begin{array}{l}\text { Values and } \\
\text { motives }\end{array}$ & Conditions and demands & Conflicts \\
\hline Activity & $\begin{array}{l}\text { The } \\
\text { imaginative } \\
\text { play of the } \\
\text { four boys } \\
\text { playing } \\
\text { dragons }\end{array}$ & & & \\
\hline Culture & $\begin{array}{l}\text { Attending } \\
\text { early } \\
\text { childhood } \\
\text { education in } \\
\text { Norway }\end{array}$ & $\begin{array}{l}\text { The dragons in } \\
\text { fairy tales have } \\
\text { been of } \\
\text { historical } \\
\text { interest for } \\
\text { decades } \\
\text { (Kværne, 2012). } \\
\text { As imaginative } \\
\text { creatures, they } \\
\text { give room for a } \\
\text { variety of ways } \\
\text { to play and } \\
\text { explore what is } \\
\text { important for } \\
\text { them, also } \\
\text { nonverbally. }\end{array}$ & $\begin{array}{l}\text { According to the teacher, 'it } \\
\text { is hard for these children to } \\
\text { engage in groups of } \\
\text { children'. } \\
\text { Formation of 'good } \\
\text { citizens': 'By participating } \\
\text { in the kindergarten } \\
\text { community, the children } \\
\text { shall be able to develop an } \\
\text { understanding of society and } \\
\text { the world in which they live. } \\
\text { Kindergartens shall promote } \\
\text { democracy and be inclusive } \\
\text { communities in which } \\
\text { everyone is allowed to } \\
\text { express themselves, be heard } \\
\text { and participate. All children } \\
\text { shall be able to experience } \\
\text { democratic participation by } \\
\text { contributing to and taking } \\
\text { part in kindergarten } \\
\text { activities regardless of their } \\
\text { communication and } \\
\text { language skills' (UDIR, } \\
2017 \text {, pp. 8-9) }\end{array}$ & $\begin{array}{l}\text { Play that is } \\
\text { emphasised in } \\
\text { education versus } \\
\text { influence from } \\
\text { cultural fiction's } \\
\text { creatures, film, } \\
\text { media, dinosaurs. } \\
\text { Being dragons and } \\
\text { crocodiles versus } \\
\text { being 'good } \\
\text { citizens'. } \\
\text { Worries for changes } \\
\text { in our democracy, } \\
\text { children leaving } \\
\text { school, emphasis on } \\
\text { early interventions } \\
\text { to prevent } \\
\text { behavioural } \\
\text { problems and crime } \\
\text { versus the } \\
\text { children's proximal } \\
\text { zone of } \\
\text { development. }\end{array}$ \\
\hline
\end{tabular}

the princess to have company versus the aim that 'all children shall be able to experience democratic participation by taking part in kindergarten activity' (UDIR, 2017 , p. 8). The activity of playing dragons does not appear as an arena to experience democratic participation, nor learn social competences, let alone seeing play as an activity in which children manage to regulate their behaviour within the rules of the play (Vygotsky, 2016; Table 5.3).

\subsubsection{Conflicts from the Perspective of Nature}

Material for analysis comprises the recorded activity, the notes on the children's and their teacher's comments, and Witoszek's (1991) outline of the Norwegian/Nordic attachment to nature. According to the children, they never played dragons inside 
Table 5.4 Conflicts from the perspective of nature

\begin{tabular}{|c|c|c|c|c|}
\hline & Social situation & Values and motives & $\begin{array}{l}\text { Conditions and } \\
\text { demands }\end{array}$ & Conflicts \\
\hline Activity & $\begin{array}{l}\text { The imaginative } \\
\text { play of the four } \\
\text { boys playing } \\
\text { dragons }\end{array}$ & & & \\
\hline Nature & $\begin{array}{l}\text { Outdoor play } \\
\text { performed } \\
\text { inside }\end{array}$ & $\begin{array}{l}\text { The free child, } \\
\text { nature as the best } \\
\text { place to be, 'play as } \\
\text { freedom', according } \\
\text { to their teacher }\end{array}$ & $\begin{array}{l}\text { Scandinavian } \\
\text { outdoor/wildlife } \\
\text { (Næss, 2005; } \\
\text { Witoszek, 1991). }\end{array}$ & $\begin{array}{l}\text { According to the teacher, } \\
\text { 'This play was inspired } \\
\text { by the weather, storms'. } \\
\text { versus cultivated } \\
\text { activities inside } \\
\text { The logocentric and } \\
\text { anthropocentric approach } \\
\text { versus the eco-centric } \\
\text { approach }\end{array}$ \\
\hline
\end{tabular}

before. A conflict emerges between dragons, the children and outdoor activities versus family role-play, (socially) competent children and indoor activities. Their teacher's comment that the weather/storms inspired their dragon play also forms a conflict to cultivated, indoor, temperate environments for play. In addition, the involved children's activity put the humans in a lower position than in the logocentric (the overall focus on language and cognitive skills) and anthropocentric approaches (the overall focus on humans) — dragons as representing nature are at the core. From this, I assume that a conflict emerges between logocentric approaches and anthropological approaches versus the eco-centric approach in which nature and non-human agents are seen as a part of the situated activity (Table 5.4).

\subsubsection{The Conflicts and What Were Explored}

From these tables, the next step in the analysis was to figure out what the children were exploring. This is illustrated in Table 5.5. The content in the middle column, labelled 'Conflicts' in Table 5.5, is the same as in the column 'Conflicts' in the four tables already presented. My interpretations of what the children were exploring are presented in the column on the right labelled 'Exploring' in Table 5.5.

From the conflicts outlined in the activity, I assume that the involved children were exploring how to be a part of a peer group. In addition, they explored how to relate to the theme in the play versus their intentions of making friends by changing the dragons into crocodiles and firefighters, and dragons that were involved in a war fighting other dragons. Thus, they were facing danger together, as friends do. From this, I assume that the involved children were exploring friendship and danger, anger and evil, and even being a danger. 
Table 5.5 The conflicts and what were explored

\begin{tabular}{l|l|l}
\hline Perspectives & Conflicts & Exploring \\
\hline Activity & $\begin{array}{l}\text { Playing together as all four in conflict with } \\
\text { splitting into two, two-person groups. } \\
\text { Dragons who are fighting and killing in conflict } \\
\text { with being friends, tickling each other and facing } \\
\text { danger together. }\end{array}$ & $\begin{array}{l}\text { Interaction in a } \\
\text { peer group } \\
\text { Friendship } \\
\text { Danger, anger } \\
\text { and evil or } \\
\text { being a danger/ } \\
\text { being evil }\end{array}$ \\
\hline Institutional perspective & $\begin{array}{l}\text { Quiet activities on the table in conflict with a } \\
\text { place for running, moving and fighting. } \\
\text { Educational content in conflict with media- } \\
\text { inspired content. } \\
\text { Didactical practices aiming at prescribed } \\
\text { definitions of good play in conflict with making } \\
\text { friends and making room for play where children } \\
\text { are in control of the temporary intent of their } \\
\text { kindergarten. }\end{array}$ & $\begin{array}{l}\text { Place } \\
\text { Space } \\
\text { Artefacts } \\
\text { Media-inspired } \\
\text { experiences } \\
\text { Their teacher's } \\
\text { didactical } \\
\text { understanding }\end{array}$ \\
\hline Cultural perspective & $\begin{array}{l}\text { Being dragons and crocodiles in conflict with } \\
\text { being 'good citizens'. Worries about changes in } \\
\text { our democracy, children dropping out of school, } \\
\text { low scores on the PISA test, emphasis on early } \\
\text { intervention to prevent behavioural problems and } \\
\text { crime in conflict with the children's proximal } \\
\text { zone of development. }\end{array}$ & $\begin{array}{l}\text { If and how } \\
\text { themes and } \\
\text { experiences of } \\
\text { importance for } \\
\text { the involved } \\
\text { children can be } \\
\text { a part of the } \\
\text { content of ECE } \\
\text { How to } \\
\text { socialize and } \\
\text { educate young } \\
\text { children }\end{array}$ \\
\hline Perspective of nature & $\begin{array}{l}\text { What to do outside in conflict with what to do } \\
\text { inside } \\
\text { Nature in conflict with culture. }\end{array}$ & $\begin{array}{l}\text { Influence of the } \\
\text { content in the } \\
\text { ECE institution }\end{array}$ \\
& $\begin{array}{l}\text { Different ways } \\
\text { of participating } \\
\text { indoors in ECE } \\
\text { institutions }\end{array}$ \\
\hline & &
\end{tabular}

From the conflicts outlined from an institutional perspective, I assume that the involved children were exploring place, space and artefacts. The irregular use of the room supplied by their teacher gave the children the space to explore more mediainspired, multicultural themes (dragons are a part of different cultures). Dragons that are imaginative creatures is a concept that is hard to define. Therefore, playing dragon forms a contrast to prescribed definitions of 'good' play. From this, I assume that the children were exploring their teacher's didactical understanding and play themes (dragons) that are of relevance for them.

From the conflicts outlined from a cultural perspective, I assume that the children were exploring how themes and experiences of importance to them can be a 
part of the content of their kindergarten. The conflict between conditions and demands for education 'to save' the future versus the values and motives from the children to play the socially incompetent dragons indicates that the children were exploring what content can be a part of ECE. It can also be assumed that the children were exploring how young children can be socialized and educated.

From the conflicts outlined from the perspective of nature, I assume that the children were exploring relations among nature, a cultivated indoor milieu, climate and humans. The involved children's exploration involved their whole body within the dramatic frame of the dragon play; they were fighting, rolling around on the floor and running to hide. In addition, nature is a part of their exploration and thereby their cultural formation. From this, I assume that the children were exploring their intra-relations to nature, indicating a more eco-centred perspective than an anthroposophical and logocentric perspective. It also paves the way to depict the impossibility of heading towards only previously defined competences, since humans (including teachers) cannot escape from nature and other actors, such as the involved (uncultivated) children, when conditioning educational practices. Thereby, the limitations for rational, cultivated humans (such as teachers) to be in total control of their practices were explored and challenged.

\subsection{Concluding Reflections}

My multifactorial analysis illustrates how a small-scale analysis that commences from an everyday activity can give insight into how the dialectical relations in different contextual perspectives interact. By presenting this methodology, we can see how a situated activity is closely connected to the larger context. What play themes are possible to be involved in, institutional factors, cultural conditions and the position of nature are woven into the present activity and are therefore perspectives that need to be taken into consideration when improving pedagogical practices in ECE.

Despite aiming at transparency and coherence, reaching these aims is a complicated task. There is a great deal of information presented in a compact form, the researcher (me) has made many challenging choices with regard to what to present and what to leave out, which call for a reflexive research practice. The epistemological position and the concepts for analysis, followed by the perspectives in the extended model, are meant to make these choices more transparent. The researcher's interpretations are thereby based on several perspectives, and so the interpretation process paves the way for several opportunities for drawing conclusions that are not valid. Nevertheless, the systematic and multifactorial analysis helped to open up the empirical material and, to a larger degree, to avoid superficial and earlier, biased interpretations. It gave room for the unexpected, because of the variety of factors that were taken into consideration to investigate what the children were exploring. Therefore, this way of analysing represents the opposite of liner causality. Further, the aims for curbing conflicts are challenged. Conflicts emerge as important both for children's development and for the researcher's insight. 
The four perspectives, including the perspective of how nature is positioned in the material for analysis, emerge through the process of analysis. The theme of the play is dragons, who are indeed not cultivated and never will be. The idea that children are being cultivated by playing these creators appears as a conflict to cultural formation. Moreover, the Nordic (Norwegian) idea resuming that humans are cultivated through nature, appear at first glance as a contradiction or in conflict with a cultural-historical approach. My experiences while doing the analysis and outlining it in text indicate that research and methods for analysis should be constantly evolving, in line with or in contrast to the changing society, changing nature and researchers who are in a constant struggle to learn and understand more, at the same time as aiming to find ways of doing research and analysis that are sustainable. It seems as though the basic ideas in dialectic approaches that emphasise conflicts make a larger space for challenging theories and methodology from (unexpected) experiences attained when doing research.

In addition, using the concept of exploring allowed for more than putting cognition, language and humans in the centre. Even though exploration is a concept that is closely connected to human activity, it leaves an opening for extending the overall focus on language and humans - there has to be something to explore. The aggregating, changing and improvisation in children's imaginative play also indicate that it is impossible for humans to be in 'full control' - and neither can the researcher. An awareness of conflicts from a variety of perspectives could help in coping with the uncertainty of never being in full control but continues our struggle for transparency and new insight when it comes to both the object of study and the methods for how to construct knowledge.

\section{References}

Biesta, G. J. (2015). Beautiful risk of education. Boulder, CO: Routledge.

Bodrova, E. (2008). Make-believe play versus academic skills: A Vygotskian approach to today's dilemma of early childhood education. European Early Childhood Education Research Journal, 16(3), 357-369.

Braidotti, R. (2016). Posthuman critical theory. In Critical posthumanism and planetary futures (pp. 13-32). New Delhi, India: Springer.

Bruce, T. (1991). Time to play in early childhood education. London: Hodder and Stoughton.

Corsaro, W. (1997). The sociology of childhood. Thousand Oaks, CA: Pine Forge Press.

Dahlberg, G., Moss, P., \& Pence, A. (2007). Beyond quality in early childhood education and care: Languages of evaluation (2nd ed.). London/New York: Routledge.

Drange, N., \& Telle, K. (2011). Gratis kjernetid i barnehage. Effekt på skolekarakterene til barn fra innvandrerfamilier. In N. P. Sandbu (Ed.), Utdanning 2011 - veien til arbeidslivet (Statistiske analyser 124). Statistisk sentralbyrå: Oslo, Norway.

Fleer, M. (2010). Early learning and development: Cultural-historical concepts in play. Cambridge, UK: Cambridge University Press.

Fleer, M., \& Veresov, N. (2018). A cultural-historical methodology for researching early childhood education. In M. Fleer \& B. van Oers (Eds.), International handbook of early childhood education (pp. 225-247). Dordrecht, The Netherlands: Springer.

Grindheim, L. T. (2013). Barns motstand som demokratisk deltaking i basebarnehagen. Utbildning och Demokrati, 22(2), 37-57. 
Grindheim, L. T. (2017). Anger and conflicts in early childhood education: Expressing worries about early intervention through the incredible years programs. In J. F. A. Cruz \& R. M. C. Sofia (Eds.), Anger and anxiety: Predictors, coping strategies, and health effects (pp. 217 238). New York: Nova Science Publishers.

Grindheim, L. T. (2018) Beyond uniform reproduction: Exploring children's imaginative play through the lenses of their teacher. Contemporary Issues in Early Childhood 146394911878338

Hedegaard, M. (2008). Developing a dialectic approach to researching children's development. In M. Hedegaard (Ed.), Studying children: A cultural-historical approach (pp. 30-45). Maidenhead, UK: McGraw-Hill Education.

Hedegaard, M. (2009). Children's development from a cultural-historical approach: Children's activity in everyday local settings as foundation for their development. Mind, Culture, and Activity, 16(1), 64-82.

Hedegaard, M. (2014). The significance of demands and motives across practices in children's learning and development: An analysis of learning in home and school. Learning, Culture and Social Interaction, 16(3), 188-194.

James, A., Jenks, C., \& Prout, A. (1998). Theorizing childhood. Cambridge, UK: Polity Press.

Kværne, P. (2012). UiO, drage. Store norske leksikon. Retrieved from https://snl.no/drage

Næss, A. (2005). Deep ecology of wisdom. Edited by Harold Glasser and Alan Drengson in cooperation with the author and with assistance from Bill Devall and George Sessions. In H. Glasser \& A. Drengson (Eds.), The selected works of Arne Naess (Vol. X). Dordrecht, The Netherlands: Springer.

Nordenbo, S. E., \& Moser, T. (2009). Forskninskortlagning og forskervurdering af skandinavisk forskning i året 2006 i institutioner for de 0-6 årige (førskole). Købehavn, Denmark: Danmarks Pædagogiske Universitetsforlag.

Norges offentlige utredninger (NOU) (2009:10). Fordelingsutvalget. Oslo, Norway: Finansdepartementet

Norges offentlige utredninger (NOU) (2011:14). Bedre integrering. Mål, strategier og tiltak. Oslo, Norway: Barne-, likestillings- og inkluderingsdepartementet.

Ødegaard, E. E. (2015). The importance of looking at someone looking through a pirate's telescope: Reflections on the making of knowledge from empirical data. Nordic Early Childhood Education Research Journal, 11(1), 1-17.

Ødegaard, E. E., \& Krüger, T. (2012). Studier av barnehagen som danningsarena. In E. E. Ødegaard (Ed.), Barnehagen som danningsarena (pp. 19-47). Bergen, Norway: Fagbokforlaget.

Payne, P. G. (2018). Early years education in the anthropocene: An ecophenomenology of children's experience. In M. Fleer \& B. van Oers (Eds.), International handbook of early childhood education (pp. 117-162). Dordrecht, The Netherlands: Springer International Handbooks of Education.

Rogoff, B. (2003). The cultural nature of human development. Oxford, UK: Oxford University Press.

Sadownik, A. R. (2017). Dark play as a misrecognized need for redistributing (digital) goods: An example from an egalitarian society. Contemporary Issues in Early Childhood, 18(2), 127-144.

Stortingsmelding (White Paper) nr. 49. (2003-2004): Mangfold gjennom inkludering og deltakelse. Oslo, Norway: Kunnskapsdepartementet.

Trippestad, T. A. (2017). The visionary position: Critical factors of utopian social engineering in education reforms. In T. A. Trippestad, A. Swennen, \& T. Werler (Eds.), The struggle for teacher education. International perspectives on governance and reforms (pp. 17-38). London: Bloomsbury Academic.

UDIR Norwegian Directorate for Education and Training. (2017). Frameworkplan for kindergartens - Content and tasks. Oslo, Norway: Norwegian Directorate for Education and Training.

Vygotsky, L. S. (2004). Imagination and creativity in childhood. Journal of Russian \& East European Psychology, 42(1), 7-97.

Vygotsky, L. S. (2016). Play and its role in the mental development of the child. Soviet Psychology, $5(3), 6-18$. 
Webster-Stratton, C. (1999). How to promote children's social and emotional competence. London: Paul Chapman/Sage.

Winther-Lindqvist, D. (2009). Game playing: Negotiating rules and identities. American Journal of Play, 2(1), 60-84.

Witoszek, N. (1991). Der Kultur møter Natur: tilfelle Norge. Samtiden, 4, 11-19.

Open Access This chapter is licensed under the terms of the Creative Commons Attribution 4.0 International License (http://creativecommons.org/licenses/by/4.0/), which permits use, sharing, adaptation, distribution and reproduction in any medium or format, as long as you give appropriate credit to the original author(s) and the source, provide a link to the Creative Commons licence and indicate if changes were made.

The images or other third party material in this chapter are included in the chapter's Creative Commons licence, unless indicated otherwise in a credit line to the material. If material is not included in the chapter's Creative Commons licence and your intended use is not permitted by statutory regulation or exceeds the permitted use, you will need to obtain permission directly from the copyright holder. 